\title{
Device Evaluation ICSR Terminology
}

National Cancer Institute

\section{Source}

National Cancer Institute. Device Evaluation ICSR Terminology. NCI Thesaurus. Code C99173.

Terminology used in Individual Case Safety Reports to specify a type of device evaluation. 